How to cite: Mănoiu, V.-M., Crăciun, Al.-I. (2019) Water Management on Board Disney Cruise Line Company Ships: Methods and Legislation. 2019 "Air and Water - Components of the Environment" Conference Proceedings, Cluj-Napoca, Romania, p. 345-356, DOI: 10.24193/AWC2019_34.

\title{
WATER MANAGEMENT ON BOARD DISNEY CRUISE LINE COMPANY SHIPS: METHODS AND LEGISLATION
}

\author{
Valentina-Mariana $\mathrm{M} \breve{A N O I U}^{I}$ 凹, Alexandru-Ioan CR $\breve{A C I U N}{ }^{2}$
}

\section{DOI: 10.24193/AWC2019_34}

\begin{abstract}
This article presents the water management on board Disney Cruise Line (DCL) company ships and it is the last one of the series dedicated to DCL waste management. In the previous papers, we focused on the environmental policies of the DCL company, on cruise itinerary waste management plans, and waste collection, sorting, storage and management on board DCL ships. This paper is based on the analysis of the ships' environmental personnel's activity, including recorded data and field observations, and of the company's internal regulations. The paper features an in-depth presentation of wastewater (gray and black water) management on board DCL cruise ships. The water is collected in special tanks, processed by an advanced wastewater purification system (AWPS), and discharged under strict control. A Wastewater (gray and black water) Log is kept on board DCL ships by the Chief Engineer. The paper also describes the White Box system used for controlling and monitoring the bilge water discharge from the vessel, and the ships' drinking water system and management. Finally, the study analyses the water management in recreational facilities, as well as ballast water management. The study concludes that the DCL company is committed to minimizing its fleet's environmental impact by green and appropriate water management procedures. The AWPS, using biological degradation, inverse osmosis and UV sterilization, results in the discharge of high-quality water, which does not require any further processing that could involve chemicals that are dangerous for the marine environment. Drinking water is brought on board DCL ships via land-based supply points and must be collected from potable sources that meet the World Health Organization standards for drinking water. Proper water management in the recreational facilities and ballast water management represent an essential part of maintaining the public and environmental health standards needed to prevent pathogen contamination, the absorption and release of harmful aquatic organisms and endangering marine sanctuaries, reservations, parks, and coral reefs. DCL has an environmentally-friendly vision and is fully committed to environmental protection.
\end{abstract}

Keywords: water management, on board, Disney Cruise Line, environment, protection

\section{INTRODUCTION}

Cruises are one of the most substantial and important components of the tourism industry (Pakbeen, 2018). Between 2011 and 2016, cruise demand

\footnotetext{
${ }^{1}$ University of Bucharest, Faculty of Geography, Department of Meteorology and Hydrology, Bd. N. Balcescu no. 1, 010041, Bucharest, Romania, valentina.mariana.manoiu@gmail.com

${ }^{2}$ PRO BIODIVERSITAS, Str. Iacobeni 31 C, Bucharest, Romania, alexandru.ioan.craciun@gmail.com
} 
increased by 20.5\% (Pakbeen, 2018; CLIA, 2018). As this sector developed, its environmental impact grew proportionally in terms of air and water pollution, disruption of aquatic biodiversity, noise pollution, generation of large amounts of solid waste (Andersson et al., 2016; Pakbeen, 2018).

Disney Cruise Line (DCL) committed to an environmentally-friendly attitude and developed a strategy for preventing any ecological degradation that could be generated by its operations (DCL, 2016). Being environmentally conscious is the key to creating an impeccable reputation and significant commercial value. Disney Cruise Line is one of the global leaders in the entertainment industry, as well as one of the "greenest" players in this field (Elks, 2013).

This article presents the water management system on board DCL company ships and it is the last one dedicated to the DCL waste management strategy. The paper's goal is to perform an in-depth analysis of wastewater (gray and black water) management on board DCL cruise ships, the ships' drinking water system and management, water management in recreational facilities, as well as ballast water management.

In the previous papers, we focused on the environmental policies of the DCL company (Manoiu and Antonescu, 2017), on the cruise itinerary waste management plans for the enterprise's ships (Manoiu and Antonescu, 2017), but also on onboard waste management plans (Manoiu and Craciun 2018), waste collection, sorting and storage and food waste management on DCL ships (Manoiu, 2018a), as well as on dangerous and medical waste management (Manoiu, 2018b).

Given its originality, the paper will complement the few scientific analyses conducted on this understudied topic (Loehr et al., 2003; Morehouse and Koch, 2003; Burgin and Hardiman, 2011; Balaji et al., 2014; Kizielewicz and Lukovic, 2015; Lasserre and Tetu, 2015; Andersson et al., 2016; Verna and Harris, 2016; Pakbeen, 2018).

Disney Cruise Line is part of the Walt Disney Company (DCL site). It was established in 1996 and was initially called Magical Cruise Company Limited. Its headquarters is located in London, UK, and its operational management is based in Celebration, Florida (DCL site). The Disney Cruise Line currently consists of four cruise ships (DCL site): Disney Magic, Disney Wonder, Disney Dream, and Disney Fantasy.

Environmental responsibilities on board DCL ships are shared between the captain, the environmental officer, the chief engineer, the class B mechanic (maintenance mechanic), and finally all crew members (Manoiu and Antonescu, 2017).

For this study, we analyzed the activity of the ships' environmental personnel, internal corporate regulations, the relevant legislation in force, and we processed the data and field observations collected by the environmental personnel.

\section{WASTEWATER MANAGEMENT}

On board DCL ships, wastewater is classified as "black water"-collected from toilets and "gray water"-collected from sinks, bathtubs and flooded floors (DCL, 2016).

Gray water is transported via the gray water pipe system to the collection tanks located in technical rooms, where it is mixed with black water and treated using the 
Advanced Wastewater Purification System (AWPS). Any sewage system-related issue is reported to the ship's Engineering Department (DCL, 2016).

Black water and gray water are collected in special tanks and then discharged when the ships' speed is of at least 5 knots and they are at least 12 nautical miles away from shore (IMO-MARPOL, 2011). The evacuation of treated black water and gray water directly from the AWPS, with no tank storage, is possible if the ship is located at a distance of at least 4 nautical miles away from shore (IMOMARPOL, 2011).

\subsection{Advanced Wastewater Purification System (AWPS)}

The system collects all amounts of black water and gray water generated on the ship. Through a process based on biological degradation, separation membrane/reverse osmosis and UV sterilization, the system's output is high quality water without using any chemicals that could be dangerous to the marine environment (DCL, 2016). The use of harmful chemicals in the purification process can disrupt or even kill the system's biological agents, which would reduce its functioning capacity. If any such chemicals are used, crew members must make sure they are approved via the MSDS (Material Safety Data Sheet) procedure before they are brought on board (DCL, 2016).

\subsection{Wastewater log (gray water and black water)}

In accordance with MARPOL and for any other applicable requirements, a logging system is used on board to document the processing, discharge or transfer to shore of any type of waste (IMO-MARPOL, 2011). The system also features a Wastewater log, managed (filled in and checked) by the ship's Chief Engineer.

The wastewater log is kept in the engine command room. Engineers record the type of water, amount in $\mathrm{m}^{3}$, the time and the AWPS discharge entry number. The National Pollutant Discharge Elimination System (NPDES) maintenance and monitoring criteria (section 5) must be met (U.S. EPA-NPDES, 2013). This log can be checked or audited by any authorized regulatory entity.

\subsection{White Data Box}

The White Box processes bilge water discharge and its oil content (Manoiu and Craciun, 2018). The bilge water is transferred to a specific tank, and then passes through the purification system and filters that separate the oil, which is collected in the sludge tank, while the water is directed to the White Box, where the oil content is checked. The White Box has 3 valves that control the oil concentration of discharged water, which must be $\leq 15$ ppm (IMO-MARPOL, 2011). If, after passing through the first valve, the oil content is $>15 \mathrm{ppm}$, the second valve closes automatically, and the water is recirculated through the purification system. The White Box and water discharge are controlled only by the engine room engineers (Manoiu and Craciun, 2018).

The environmental officer keeps the mandatory back-up, White Box data and chart archive, in a special folder on drive C: of the Environmental Department 
computer. White Box data include the location, time, flow rates and oil content (ppm) in the discharged bilge water (Manoiu and Craciun, 2018). For example, the bilge water volume discharged in Port Canaveral by large ships such as Disney Fantasy is 30-40 tons/week (DCL, 2016).

On a monthly basis, the environmental officer accesses the server data using the White Box review software and follows these compulsory steps: transfers data and creates charts; saves a copy of monthly data and the graph stored on the environmental department computer; makes sure the data can be accessed by inspectors, agents and officers who wish to review the information; sends a copy of the monthly data to the technical operations department, where it will be logged in the AMOS software. White Box data is kept for three years, similarly to Oil Log data (IMO-MARPOL, 2011).

\section{POTABLE WATER MANAGEMENT AND SYSTEM}

Vessel Sanitation Program (VSP) requirements with regard to potable water management must be met at all times (U.S. CDCP-VSP, 2018).

The potable water system is a critical component in a ship's public health structure. It provides potable water for all ships sectors, including catering and medical units.

Potable water is transferred on board via on-shore supply stations which collect water from potable sources that meet the World Health Organization's potable water standards. The ship must hold a copy of the most recent microbiological report from each harbor (no older than 30 days), which also entails an E. coli (Escherichia coli) test, before transferring the water on board (U.S. CDCP-VSP, 2018).

Water samples collected and analyzed to determine the presence of E. coli may be substituted by the microbiological report for each water system in each port. If a ship is supplied with potable water in the same harbor more than once a month, a single monthly test is necessary. Once the ship leaves the harbor, the potable water system requires a reverse osmosis unit, distillation units or other water supply procedures/installations. These processes must not be activated in polluted areas, harbors or when the ship is anchored at sea. In such instances, reverse osmosis units, evaporation processes, pipe systems or other installations that are completely separated from the potable water system can be used, but only to produce industrial water (U.S. CDCP-VSP, 2018).

\subsection{Halogenation and $\mathrm{pH}$ control during supply and water production operations}

During the potable water supply process, all precautionary measures must be taken to ensure water safety and quality, in full compliance with naval health program requirements (U.S. CDCP-VSP, 2018).

Potable water must be continuously halogenated at least at $2.0 \mathrm{mg} / \mathrm{l}(\mathrm{ppm})$ free residual halogen during supply or production operations. The $\mathrm{pH}$ must be adjusted 
so as not to exceed the 7.8 threshold. The free residual halogen must be adjusted at a minimum level of $2.0 \mathrm{mg} / \mathrm{l}(\mathrm{ppm})$ within 30 minutes after the supply and production operations start (U.S. CDCP-VSP, 2018).

A free residual halogen and $\mathrm{pH}$ test must be conducted at the on-shore water supply unit before the potable water supply process starts in order to set the correct halogen dosage. Test results must be recorded and made available for future inspections.

Once the free residual halogen level reaches at least $2.0 \mathrm{mg} / \mathrm{l}(\mathrm{ppm})$, and the $\mathrm{pH}$ level is below 7.8, the two parameters are monitored and tested every hour during the supply process, and every 4 hours during the potable water production process. Monitoring records must be kept on board for at least 12 months and must be made available for inspections (U.S. CDCP-VSP, 2018).

Water samples for halogen and $\mathrm{pH}$ tests must be collected from a sample valve and/or a halogen analyzer probe, located on the water pipe at least 3 meters (10 feet) after the halogen injection point and before the storage tank (U.S. CDCPVSP, 2018).

\subsection{Potable water system}

Potable water tanks must not share any walls with the ship's body or with tanks and/or pipes used for non-potable water or other liquids. Pipe systems used for wastewater or other non-potable liquids must not enter into contact with potable water tanks. Non-potable water pipes located above potable water tanks must not feature any mechanical coupling. Potable water tanks must be identified with a number and the words "POTABLE WATER" must be written on them using at least a $13-\mathrm{mm}(0.5 \mathrm{inch})$ font. Potable water pipes must be painted in stripes, in accordance with ISO 14726 standards (blue/green/blue), or only in blue (Pipe Identification Tape to ISO 14726). Potable water pipes must not pass under or through tanks containing non-potable liquids.

The potable water supply pipe of the supply unit must start either horizontally or downward, and at least $460 \mathrm{~mm}$ (18 inches) above the supply unit deck (U.S. CDCP-VSP, 2018).

Potable water pipes must be labeled with the mention "POTABLE WATER ONLY", in 13-mm (0.5 inch) letters, at each connection end (U.S. CDCP-VSP, 2018).

\subsection{Potable water tank and distribution system decontamination and disinfection}

Potable water tanks and all distribution system elements must be emptied, cleaned and disinfected: before being put into service; before being put into service after repairs or replacements; after being subjected to any type of contamination.

Potable water tanks must be inspected, cleaned and disinfected in dry and wet docks or every 2 years. The documentation regarding all inspections, maintenance, cleaning and disinfection procedures must be kept for 12 months and must be made available during inspections. Records must include disinfection methods, 
concentrations and contact times, and mention halogen values lower than or equal to $5 \mathrm{ppm}$ before the tank is put into service (U.S. CDCP-VSP, 2018).

In case of contamination, the disinfection process must entail the increase of the free residual halogen level up to at least $50 \mathrm{mg} / \mathrm{l}(\mathrm{ppm})$ across the entire affected area; this concentration will be maintained for 4 hours. Alternatively, another VSPapproved procedure can be used (U.S. CDCP-VSP, 2018). In case of emergency, the contact time can be reduced by 1 hour by increasing the free residual halogen concentration up to at least $200 \mathrm{mg} / \mathrm{l}(\mathrm{ppm})$ across the entire affected area. The post-contamination disinfection process must be thoroughly documented.

\subsection{Potable water chemical treatment system}

The halogen injection equipment must ensure the continuous halogenation of the potable water distribution system and must maintain a free residual halogen level of $\geq 0.2 \mathrm{mg} / \mathrm{l}(\mathrm{ppm})$ and $\leq 5.0 \mathrm{mg} / \mathrm{l}(\mathrm{ppm})$ in the entire distribution system (U.S. CDCP-VSP, 2018). The amount of chemicals injected in the potable water system must be controlled via an analyzer. At least one automatically activated back-up halogen pump must be installed in order to maintain the necessary free residual halogen level in case the main pump malfunctions.

A halogen analysis and recording graph must be installed in the water distribution system, in a point with a high water flow rate. Instead of chart-type loggers, high-safety automatic electronic data recording systems can be used. A manual calibration comparison test must be conducted daily and recorded in a chart or log. In case of equipment malfunction, the free residual halogen must be measured with a manual test kit at least every 4 hours (U.S. CDCP-VSP, 2018).

\subsection{Microbiological monitoring}

At least four potable water samples must be analyzed for E. coli on a monthly basis. The samples must be collected from the ship's bow, stern and upper and lower decks. Sampling locations must be changed each time in order to ensure a full coverage of the potable water distribution system. The samples must be analyzed using the Standard Methods for water and wastewater analysis (Standard Methods site). Test kits, incubators and associated equipment must be operated and maintained in accordance with the manufacturers' specifications. Test results must be kept on board for at least 12 months and must be available for inspection. The potable water distribution system and its connections must be fitted with protection against reflux.

\section{WATER MANAGEMENT IN RECREATIONAL FACILITIES}

The proper management of water installations in a ship's recreational facilities is an essential part of meeting public health standards in order to prevent contamination with pathogens and is one of the responsibilities of the Environmental Department (DCL, 2016). According to naval health program 
requirements (U.S. CDCP-VSP, 2018), the water supplied to all recreational facilities must be potable water or seawater. The entire volume of water used in recreational facilities must pass through all the components of the recirculation system (filtration, chlorination, $\mathrm{pH}$ control). Recirculation systems and equipment, including chemical control equipment, UV disinfection systems, filters and pumps, must be designed so as to maintain an adequate water chemistry during operation at the following recirculation rates (U.S. CDCP-VSP, 2018) (Table 1):

Table 1. Water recirculation rates in recreational facilities (U.S. CDCP-VSP, 2018)

\begin{tabular}{|c|c|}
\hline Recreational facilities & $\begin{array}{c}\text { Recirculation rate } \\
\text { (hours) }\end{array}$ \\
\hline Pools & 4 \\
\hline Pools for children & 0.5 \\
\hline SPA Jacuzzi & 0.5 \\
\hline SPA pool & 2 \\
\hline $\begin{array}{c}\text { Recreational facilities with interactive activities } \\
\text { (depth <610 mm) }\end{array}$ & 1 \\
\hline $\begin{array}{c}\text { Recreational facilities with interactive activities } \\
\text { (depth > 610 mm) }\end{array}$ & 2 \\
\hline Recreational facilities for children in diapers & 0.5 \\
\hline
\end{tabular}

Note: regarding recreational facilities for children in diapers, the entire water volume must pass through all system components (filtering, secondary UV disinfection and halogenation) at least once every half-hour. In order to ensure a permanent control of filtering, UV disinfection, halogenation and $\mathrm{pH}$, the entire system must be functional at all times.

Recirculated water from recreational facilities must be filtered as follows (Disney Cruise Line uses granular filters): SPA Jacuzzis and SPA pools: every day (every 72 hours, according to VSP) (U.S. CDCP-VSP, 2018); water from recreational facilities for children in diapers: every day; water from all other recreational facilities: as recommended by manufacturers.

Granular filters must be examined for cracks, build-ups or holes. The build-up of excess organic matter is checked using a VSP-recommended method (U.S. CDCP-VSP, 2018). For SPA Jacuzzis and pools, sedimentation inspections and tests must be conducted monthly, while all other recreational facilities must be inspected on a quarterly basis. Recreational facility filters must be cleaned of hair and lint, rinsed and disinfected on a weekly basis. In the disinfection process, a proper (at least $50 \mathrm{ppm}$ solution, contact time: 1 minute) halogen-based disinfectant must be used. All cleaning and disinfection processes must be logged and made available to inspectors.

Automatic systems must be installed for halogen-based disinfection and $\mathrm{pH}$ control. Injected volumes must be controlled by flow meters or free residual halogen and $\mathrm{pH}$ analyzers. Free residual halogen must be maintained in the recirculated water of recreational facilities at the levels presented below (Table 2). 
$\mathrm{pH}$ levels must not fall outside the 7.0-7.8 interval. Any facilities in which these halogen and $\mathrm{pH}$ levels are not maintained must be shut down immediately.

Table 2. DCL standards on injected amounts of free residual halogen (U.S. CDCP-VSP, 2018)

\begin{tabular}{|c|c|}
\hline Recreational facilities & $\begin{array}{c}\text { Free residual halogen } \\
\mathbf{~} \mathbf{g} / \mathbf{l}(\mathbf{p p m})\end{array}$ \\
\hline POOLS for swimming & $\geq 1.0$ and $\leq 5.0$ \\
\hline POOLS for children & $\geq 1.0$ and $\leq 5.0$ \\
\hline POOLS with interactive activities & $\geq 2.0$ and $\leq 5.0$ \\
\hline POOLS for children in diapers & $\geq 3.0$ and $\leq 10.0$ unchlorinated \\
\hline & $\geq 4.0$ and $\leq 10.0$ bromine \\
\hline SPA Jacuzzis and SPA pools & $\geq 3.0$ and $\leq 10.0$ unchlorinated \\
\hline & $\geq 4.0$ and $\leq 10.0$ bromine \\
\hline
\end{tabular}

Free residual halogen and $\mathrm{pH}$ monitoring is performed using loggers or electronic data charts that record $\mathrm{pH}$ and halogen values for each recreational facility. In case of equipment malfunction, the free residual halogen and $\mathrm{pH}$ must be measured using a manual test kit, at least every hour for SPA Jacuzzis, SPA pools and children's pools, and every 4 hours for all other recreational facilities. A manual free residual halogen and $\mathrm{pH}$ calibration test must be completed before the facilities are put into service (U.S. CDCP-VSP, 2018).

\subsection{Accidental swimming pool and spa spills}

The employee in charge of the recreational facility in question must close it immediately and inform the environmental officer of the incident. The environmental officer will contact the captain and staff captain to inform them of the incident, after which Guest Services and Port Adventure will be notified that the facility is temporarily closed (U.S. CDCP-VSP, 2018).

The environmental officer must make sure that all the necessary steps featured in the environmental section of the accidental spill form are followed. The filtration system must be turned off. All visible residues in the recreational facility must be collected and discharged in the sewage system. All tools used for removal and cleaning procedures must be disinfected in 50\% chlorine for 5 minutes. The pool's filtration system must be washed and disinfected (U.S. CDCP-VSP, 2018).

Chlorine is added to disinfect the facility. In case of loose stool, chlorine up to $250 \mathrm{ppm}$ must be used for 62 minutes. In case of solid stool or vomit, $5 \mathrm{ppm}$ chlorine must be used for 10 minutes and the $\mathrm{pH}$ is maintained between 7.2 and 7.5 during the disinfection process (U.S. CDCP-VSP, 2018).

The water is neutralized, drained from the pool, which must be washed with the proper detergents. The entire surface is then cleaned abrasively and rinsed with high pressure water. The facility is refilled with water and $1-5 \mathrm{ppm}$ chlorine is added. The filters must be washed and disinfected (U.S. CDCP-VSP, 2018). 
The facility's water filtration system is activated while the water is tested to ensure a chlorine concentration between 1-5 ppm at a $\mathrm{pH}$ of 7.0-7.8, which must be maintained for at least 15 minutes before people are allowed to reenter.

The environmental officer contacts the captain, staff captain, guest services and port adventures when the recreational facility reopens. All feces/vomit-related incidents must be recorded in a log along with the following information: facility name; date and time of event; number of people present in the water; solid/loose stool or vomit; chlorine used for disinfection; disinfectant contact time; disinfection/re-opening pH; chlorine used for re-opening (U.S. CDCP-VSP, 2018).

\section{BALLAST WATER MANAGEMENT}

The company policy also includes the proper ballast water management according to IMO (International Maritime Organization) (IMO site, Ballast Water Management) regulations in order to minimize the absorption and release of harmful aquatic organisms, pathogens and sediments. This may entail the exchange of ballast water in deep open sea areas in order to limit the risk of transfer of coastal water or aquatic species.

For cruises to the US, any of the practices below can be used: 1 . Ballast water exchange in an area located no less than 200 nautical miles from any shore, before entering US waters. The exchange must be done "sequentially" (tanks are emptied and refilled with ocean water) or in a "continuous water flow" manner (tanks are simultaneously emptied and refilled with ocean water). 2. Ballast water is retained onboard. 3. An alternative ballast water management method is used - approved by the US Coast Guard (no such alternative has been approved for Disney ships). 4. Ballast water is discharged to an approved transfer facility (IMO-BWM, 2004).

The captain is not required to perform any ballast water management procedure (including exchange) if he/she decides this action threatens the safety of the ship, crew or passengers due to unfavorable weather conditions, vessel design limitations, equipment failures or any other extraordinary conditions. In this situation, only minimal amounts of ballast water must be discharged, which are operationally necessary to ensure safe loading operations (DCL-Engineer Department, 2016).

If a ship enters US waters after cruising outside the exclusive economic zone (EEZ), but without being able to exchange ballast water because of the 200nautical mile limit, the ship must keep the ballast water load unchanged while operating in US waters, and only the minimal amounts of unchanged ballast water that are operationally required to ensure safe cargo operations can be discharged (IMO-BWM, 2004; DCL-Engineer Department, 2016).

The necessary precautionary ballast water discharge measures are as follows (IMO-BWM, 2004; DCL-Engineer Department, 2016):

- all ships must avoid discharging or exchanging ballast water in areas that could directly affect marine sanctuaries and reserves, marine parks or coral reefs; 
- ballast water exchange should be minimized or avoided in: areas known to be infested or populated by harmful organisms and pathogens (e.g. toxic algae); the vicinity of sewages and dredging operations; areas where tides are known to be low or when a tidal stream is known to be turbid; shallow water, if the propellers can disrupt and mix sediments; convergence areas and whale feeding grounds; shallow water at nighttime, when deep-sea organisms may emerge to the surface;

- ballast tanks must be cleaned regularly (sediment removal) out in the ocean or in controlled harbor sectors or dry docks. When the ship is in US waters, only the minimal amounts of ballast water required for operations can be discharged.

When the ship is in US waters, the captain or the crew member in charge files a precise report on Ballast Water Management in accordance with 33 CFR 151.2041 (CFR, 2005). All ballast water management actions must be logged, and the documents kept on board for at least 3 years, as per 33 CFR 151.2045 (CFR, 2009).

\section{CONCLUSIONS}

One of the ways in which DCL's fleet aims to minimize its environmental impact and contribute to marine conservation consists of a sound onboard water eco-management (wastewater, drinking water, recreational facilities water, bilge water and ballast water), which uses the most modern technology in the industry.

Black water and gray water are treated using the Advanced Wastewater Purification System (AWPS) and then discharged, while respecting certain conditions in terms of distance to shore and ship speed. AWPS (based on biological degradation, reverse osmosis and UV sterilization) generates high-quality "environmentally-friendly" water. Wastewater management activities are recorded in the Waste Water Log; those relating to bilge water management (filtration and purification) entail using the White Box. Potable water is transferred on board from on-shore supply units, and all sources must comply with the World Health Organization's potable water standards. Potable water must be continuously halogenated in the distribution system and must be tested periodically for E. coli.

The proper water management in recreational facilities prevents pathogen contamination on DCL ships. The recreational facility water is potable water or seawater. The entire volume used in recreational facilities must pass through all components of the recirculation system (filtration, chlorination, $\mathrm{pH}$ control). The responsible ballast water management on DCL vessels minimizes the absorption and release of harmful aquatic organisms, pathogens and sediments, and avoids endangering marine sanctuaries and reserves, marine parks and coral reefs.

The proper water management onboard company ships was one of the factors that led, in 2013, to DCL being declared the most environmentally-responsible cruise line, according to the Cruise Industry Environmental Report Card (Elks, 2013). The company complies with all national and international environmental conventions, laws and regulations regarding wastewater, drinking water, 
recreational facilities water, bilge water and ballast water. DCL has an unequivocal eco-friendly vision and is fully committed to environmental protection.

\section{ACKNOWLEDGEMENTS}

The two authors contributed equally in conducting the research and preparing the manuscript.

\section{REFERENCES}

1. Andersson K., Brynolf S., Lindgren J.F., Wilewska-Bien M. (2016), Shipping and the environment, Berlin: Springer.

2. Balaji R., Yaakob O., Koh K.K. (2014), A review of developments in ballast water management. Environmental Reviews, 22(3), 298-310. DOI: 10.1139/er2013-0073.

3. Burgin S., Hardiman N. (2011), The direct physical, chemical and biotic impacts on Australian coastal waters due to recreational boating. Biodiversity and Conservation, 20(4), 683-701. DOI: 10.1007/s10531-011-0003-6.

4. Code of Federal Regulations (2005), What are the mandatory ballast water reporting requirements. Title 33, Sec. 151.2041 (33 CFR 151.2041), 299-300. U.S. Government Publishing Office.

5. Code of Federal Regulations (2009), What are the mandatory recordkeeping requirements for vessels equipped with ballast tanks that are bound for a port or place in the United States. Title 33, Sec. 151.2045 (33 CFR 151.2045), 280-281. U.S. Government Publishing Office.

6. Cruise Lines International Association (CLIA) (2018), Cruise industry outlook. URL: $\quad$ https://cruising.org/docs/defaultsource/research/clia-2018-state-of-theindustry.pdf? sfursn=2. Accessed on 15.11.2018.

7. Disney Cruise Line site. URL: https://disneycruise.disney.go.com/. Accessed on 12.11.2018.

8. Disney Cruise Line (2016), Safety Management System. Environmental Aspects. England: Magical Cruise Company Limited.

9. Disney Cruise Line - Engineer Department (2016), Ballast Water Management. England: Magical Cruise Company Limited.

10. Elks J. (2013), Disney Scores the Only "A" on Cruise Industry Environmental Report Card [online], URL: https://www.sustainablebrands.com/news_and_views/communications/jennifer-

elks/disney-scores-only-cruise-industry-environmental-report-. Accessed on 1.11.2018.

11. International Maritime Organization (IMO) site. Ballast Water Management. URL: http://www.imo.org/en/OurWork/Environment/BallastWaterManagement/Pages/Def ault.aspx. Accessed on 03.11.2018.

12. International Maritime Organization (IMO) (2004), International Convention for the Control and Management of Ships' Ballast Water and Sediments (BWM). IMO Publishing.

13. International Maritime Organization (IMO) (2011), International Convention for the Prevention of Pollution from Ships (MARPOL). 5th edition. IMO Publishing. 
14. Kizielewicz J., Lukovic T. (2015), Negative Impact of Cruise Tourism Development on Local Community and the Environment, Information. Communication and Environment: Marine Navigation and Safety of Sea Transportation, 243-250.

15. Lasserre F., Tetu P.L. (2015), The cruise tourism industry in the Canadian Arctic: analysis of activities and perceptions of cruise ship operators. Polar Record, 51(1), 24-38. DOI: 10.1017/S0032247413000508.

16. Loehr L.C., Ehrman H., Atkinson M., George K., Beegle-Krause C.J. (2003), Using a simple dilution model to estimate wastewater contaminant concentrations behind moving passenger vessels, OCEANS 2003 MTS/IEEE: Conference on Celebrating the Past - Teaming Toward the Future, 390-393.

17. Manoiu V.-M., Antonescu M. (2017), Disney Cruise Line Environmental Management. Part I: Environmental Policy and Waste Management on Cruise Itineraries. Papers of the "Dimitrie Cantemir" Geographic Seminar, 45(2), 89-108.

18. Manoiu V.-M. (2018a), Waste Collection, Sorting and Storage and Food Waste Management on Disney Cruise Line Ships. Proceedings Volume of ISF 2018, Prague, European Scientific Institute. DOI:10.19044/esj.2018.c4p1

19. Manoiu V.-M. (2018b), Dangerous and Medical Waste Management on Board Disney Cruise Line Company Ships. Proceedings Volume of ADVED 2018 Conference, Istanbul. ISBN: 978-605-82433-4-7.

20. Mănoiu V.-M., Crăciun A.-I. (2018), Waste Management on Board Disney Cruise Line Company Ships. Papers of the "Dimitrie Cantemir" Geographic Seminar, 46(2), 77-99. http://dx.doi.org/10.15551/lsgdc.v46i2.06.

21. Morehouse C., Koch D. (2003), Alaska's cruise ship initiative and the commercial passenger vessel environmental compliance program. OCEANS 2003 MTS/IEEE: Conference on Celebrating the Past - Teaming Toward the Future, 372-375.

22. Pakbeen H. (2018), Comparative Study of Leading Cruise Lines' Sustainability Practices and Environmental Stewardship in Contribution to SDGs' Sea and Water Conservation Goal. European Journal of Sustainable Development, 7(3), 507-516. DOI: $10.14207 /$ ejsd.2018.v7n3p507.

23. Pipe Identification Tape to ISO 14726. URL: https://cdn1.shipserv.com/ShipServ/pages/attachments/231097ma/1034SS0617w.pdf. Accessed on 05.11.2018.

24. Standard Methods site. Examination of Water and Wastewater. URL: https://www.standardmethods.org/. Accessed on 10.11.2018.

25. U.S. Centers for Disease Control and Prevention (CDCP) (2018), Vessel Sanitation Program (VSP). URL: https://www.cdc.gov/nceh/vsp/pub/pub.htm. Accessed on 07.11.2018.

26. U.S. Environmental Protection Agency (EPA) - National Pollutant Discharge Elimination System (NPDES) (2013), Vessel General Permit for Discharges Incidental to the Normal Operation of Vessels (VGP). URL: https://www3.epa.gov/npdes/pubs/vgp_permit2013.pdf. Accessed on 20.11.2018.

27. Verna D.E., Harris B.P. (2016), Review of ballast water management policy and associated implications for Alaska. Marine Policy, 70, 1321.DOI: 10.1016/j.marpol.2016.04.024. 